\title{
Sum Urine Volume
}

National Cancer Institute

\section{Source}

National Cancer Institute. Sum Urine Volume. NCI Thesaurus. Code C85817.

The sum of urine volumes that are collected over time. 